\title{
Europeanism in the Comprehension of F. Dostoevsky: The Antique Aspect
}

\author{
Anna Skoropadskaya \\ Institute of Philology, Petrozavodsk State University, Petrozavovdsk, Russia \\ Corrsponding author. E-mail: san19770@mail.ru

\begin{abstract}
The article analyzes the understanding of Europeanism in F. Dostoevsky's journalism. One of the central topics for the Russian writer - the contrast between Europe and Russia - is revealed by referring to the ancient tradition. Antiquity, which laid the foundations of European culture, becomes one of the keys to understanding the possible resolution of the ideological contradiction. Antiquity and Christianity turn into models of the pan-human, from which the national grows.
\end{abstract}

Keywords: Dostoevsky, Europeanism, the ancient tradition, classical education

\section{INTRODUCTION}

Fedor Dostoevsky is the most famous Russian writer in the West. It is his works that have become the personification of the Russian soul and Russian culture for the foreign reader. Not only is such popularity due to the worldview depth of Dostoevsky's works, but also, to some extent, to a universal literary language that is clear to European people. "Dostoevsky can be translated" [1], which means that he is congruent to some general cultural context. According to N. Berdyaev, "Dostoevsky's works are the Russian word about the pan-human. And this makes him the most interesting writer for western Europeans among all other Russian writers"[2].

Meanwhile, Dostoevsky the thinker was quite critical of Europe contemporary to him. However, his established reputation of an anti-westerner is not so definite. The Russian writer Dostoevsky, denying modern European culture, remained rooted in the European tradition, which has a centuries-old spiritual experience.

\section{METHODS AND MATERIALS}

The purpose of this article is to clarify the role of ancient tradition in shaping Dostoevsky's views on Europe and Europeanism. The study is based on the general scientific method of comparative analysis, as well as on particular methods of philology, i.e. the biographical method, contextual and intertextual analysis. In accordance with the chosen methods, we turn to Dostoevsky's journalistic and literary texts in which the writer mentions the theme of Europeanism.

\section{EUROPEAN AND ANTIQUE}

\subsection{European and Russian culture in the light of the ancient tradition}

The role of Europe in Russian political and cultural development is evaluated differently, but it is never denied by anyone. The study of Europeanism in Russia (Russian Europeanism) has a rich history. Specialists of various humanitarian fields (history, political science, cultural studies, philology) have approached this topic trying to reveal its depth and versatility. Dostoevsky in the context of this scientific problem is not ignored.

Relying on this scientific experience, we will turn to the aspect which has still remained in the background. Its invisibility is due not to its insignificance, but to its evidence. The fact is that the fundamental role of antiquity in the formation of European culture is considered once and for all a proven fact. Why prove what has already been proven? For European culture, antiquity becomes a common background, natural in its perception. And when Russian culture and Russian literature embark on the "European path", antique themes, antique images and motifs are used in an open and, to some extent, straightforward manner. Therefore, the themes like "Lomonosov and Antiquity", "Zhukovsky and Antiquity", "Pushkin and Antiquity" are so easy to understand ... Meanwhile, from the mid-19th century there has been a rejection (largely external) of antique samples, and a connection of, for example, Turgenev, Tolstoy, Dostoevsky with the ancient tradition does not appear to be obvious. However, due to numerous historical and cultural factors, not only must this connection be assumed, but affirmed. After all the entire enlightened Russian society was introduced to antiquity through the educational system which was based on the European model and included the disciplines of the 
ancient cycle (Latin and ancient Greek, ancient rhetoric, literature, philosophy). Antiquity influenced the formation of reading preferences, the visual arts, theatre and architecture. In the latter case, St. Petersburg, founded by Peter the Great as a European city imbued with ancient aesthetics, is a striking example.

\subsection{Dostoevsky and the ancient tradition}

Dostoevsky was not simply familiar with antiquity. He knew it. Thus he was fluent in Latin, well versed in ancient literature, historiography and philosophy. The description of Dostoevsky's last lifetime library [3] contains the works of Homer, Xenophon, Tacitus, Plato, Aeschylus, Caesar, to whom the Russian writer appeals in his texts and private notes. Dostoevsky's overseas trips allowed him to come into contact with material evidence of the ancient era and ancient art (especially in Italy and Rome). Evaluating this contact with antiquity, one should not overlook the mediating role of European literature, about many representatives of which (Shakespeare, Goethe, Cervantes, Schiller, Balzac, etc.) Dostoevsky was sincerely passionate. According to T. G. Malchukova, the ancient tradition was fundamental for all national European literatures, and each national secular literature had a common classical Greek-Roman basis [4].

Due to the realism of Dostoevsky's artistic method antiquity does not appear openly and bluntly in his works, but the ancient aesthetic and philosophical tradition is laid in the foundation of the ideological and artistic content of the texts. This requires a special philological analysis, which is beyond the scope of the article. Journalism, epistolography and diary entries reveal a direct appeal to certain components of ancient culture. Not only does this help to clarify the author's review of the ancient tradition, but also makes it possible to reconstruct the understanding of concepts that are significant for the writer, among which Europeanism occupies an important place.

\subsection{The role of Europe in the assessment of Westerners, Slavophiles and Pochvennichestvo movement}

The "Golden Age" of Russian literature came in the 19th century. In historical and cultural terms it was the period of national self-identification, a craving for determining the position of Russia in the global historical process. The definition of the European civilization role in the formation of Russian culture becomes the central problem for the thinking circles. In the emerging intercultural dialogue two opposing camps were identified - the so-called "Westerners" and "Slavophiles". The former claimed the undoubted leadership of Europe and its civilizational achievements, while the latter defended the primacy of Russian national identity. It is important to understand that this ideological confrontation was not straightforward, "the indicated lines existed implicitly, their elements were not divided, but combined and intertwined within the framework of one mind" [5].
The term "(Russian) Europeanism" appears in the 1840s thanks to A. Herzen [6]. Interpreting this term primarily as a commitment to western values, Russian intellectuals gave it an assessment from the standpoint of their own convictions. Westerners pointed to the positive development according to the western model; Slavophiles criticized such imitation.

Not adjoining either camp, Dostoevsky formulates his own worldview concept called pochvennichestvo (roughly translated as "native soil"). By pochva (soil) Dostoevsky understood "everything that gives birth and unites: people, motherland, native language and native land. They are all linked together by the mystery of Russia" [7] Pochvenniki (followers of Pochvennichestvo) tried to take into account Westerners and Slavophiles's achievements and mistakes and determine the correct vector for the development of Russia. Despite the secondary nature of their views "representatives of this concept understood that the ideas put forward by them synthesized everything that was considered to be the most fruitful and that was developed by various movements in Russia" [8].

In this ideological context the role of Europe remained the focus of attention. The critical attitude towards it was not an absolute denial of its cultural and spiritual achievements. In "The Diary of a Writer", the entry from June, 1876, Dostoevsky writes, "We, Russians, have two motherlands Russia and Europe - even in cases when we call ourselves Slavophiles: let them not be angry at me for this remark. This should not be disputed. The greatest among their great future designations, already apperceived by the Russians, is the designation common to the whole human race-service rendered to mankind as a whole, not only to Russia, not only to Slavs in general, but to humankind in toto." [9] Russian acceptance of Europe encounters Europe's reluctance to accept Russians. Dostoevsky introduces the concepts of the common human and the pan-human thus finding a solution of the emerging contradiction. Pushkin is an example of such a solution at the art level, "For wasn't he capable of embracing in his soul foreign genius as his own? In art, at least, in creative achievement, he has indubitably revealed this universality of the Russian spirit, and this in itself is a great indication." [9].

Dostoevsky explicitly formulated his pochvennichestvo ideology in his journalistic texts. Referring to this side of the Russian writer's work helps to reveal his ideological pursuit in the interpretation of relations between Russia and Europe.

\section{EXPLICIT AND IMPLICIT COMPREHENSION OF EUROPEANISM}

Dostoevsky is best known as a writer and thinker. However, journalism became an equally important area for the realization of his talent. Turning to the journalistic genre allowed Dostoevsky to "synthesize facts of reality with writer's impressions" [10]. Most deeply Dostoevsky's journalism was embodied in "The Diary of a Writer." Combining the scientific and artistic methods the author does not just experiment in the field of genre and style, but he turns to contemporary burning issues incorporating them in the global and timeless context. In his literary texts 
Dostoevsky figuratively and symbolically reveals these issues, living them together with his characters.

\subsection{The Ideal of the Iliad}

In journalism, addressing pressing social and political issues, Dostoevsky often appealed to literature. Not so much is this technique due to Dostoevsky's affiliation with the writing community as to the social and literary character of all Russian thought. In 1861, the Vremya magazine, edited by the Dostoevsky brothers, published "A Series of Articles on Russian Literature", which became Fyodor Dostoevsky's first serious journalistic experience. Turning to a critical analysis of contemporary literature, Dostoevsky declares his aesthetic and ideological position.

In the second article of the series, "Mr. bov and the Question of Art," Dostoevsky argues with N. Dobrolyubov and his utilitarian approach to literature. To confirm his position, he turns to Homer's Iliad as the most striking example of a combination of highly spiritual content and aesthetically perfect execution. In particular, Dostoevsky thus explains the significance of Homer's poem for contemporary art, "this is the epic of such a powerful, full life, such a high moment in the life of the people, and, we also note, the life of such a glorious race that in our time, in the time of aspirations, struggle, hesitation and faith (because our time is the time of faith), in a word, in our time of greatest life, this eternal harmony embodied in the Iliad might too decisively affect the soul "[11]. It is in his discourse about Homer's epos where Dostoevsky begins to use the category of the common human, which will culminate in his "Pushkin. A Sketch". Homer's eternal ideal does not belong only to the Greeks, it became an ideal for all European culture, and for Russian culture as well: "The literature of European peoples was almost native to us, almost our own, completely reflected in Russian life, just like at home" [11]. The whole power of the Iliad is not in the genius of its creator and not in its artistic perfection; the ancient poem, being a folk poem first of all, comes from the origins of the ethnos, and therefore becomes eternal and close to other, new, peoples. This becomes one of the reasons for Dostoevsky to reject the "exclusively European form of civilization" and to affirm the common human role of art and education.

\subsection{Theme of Russia and Europe in "The Diary of a Writer"}

The Diary of a Writer is an amazing in its genre and semantic content project of Dostoevsky, [12]. Turning to the facts of modern reality and the events of real life Dostoevsky subjected them to deep socio-political and philosophical analysis. The writer outlined the topic of relations between Russia and Europe in the first materials collected for the future "Diary" [13], and it was then raised in most of its issues. In particular, it can be stated that Dostoyevsky's understanding of Europeanism was finally formed there.

The term Europeanism itself is not often found on the pages of the "Diary ...". However, the context of its use testifies to the value system developed by Dostoevsky.
Thus Europeanism becomes a characteristic of the educated class. Moreover, this characteristic gains a negative connotation with the epithets "proud", "fake", "false" being applied to it. For example, "it is $\langle\ldots\rangle$ so instructive, $<\ldots>$ to trace to what an extent this theoretical Europeanism has falsely alienated itself from the people and from society, to what an extent its views and dicta, at certain extraordinary moments of public life-though presumptuous and haughty as heretofore - are, essentially, weak, unsteady, obscure and erroneous in comparison with the clear, simple, firm and unflinching inferences of the popular sentiment and mind" [9].

Most disgustingly Europeanism is manifested in officials. An ironic play on the term is put into the mouth of a bureaucrat who proves that the bureaucracy is the state: "this is we, we alone. We are the incarnation of the whole formula of Russian Europeanism; it resides in toto in us. We alone are also its interpreters. And I can't see why they shouldn't be receiving duly established decorations for their Europeanism if we are merging with them so innocently!" [9]. A man in power, as a rule, fancies himself as a European and despises Russia. Its vivid illustration is the scene from the "Diary of a Writer" for August 1880, in which a state courier beating a coachman is depicted: "the flaps of his uniform, his feathered hat, his polished Petersburg boots, to him were spiritually dearer not only than the Russian peasant, but perhaps than Russia in toto, $<_{\ldots}>$ in which, probably, he found nothing remarkable or worthy of note other than his own fist or the kick of his polished boot" [9]. Such "Europeanism" is a consequence of borrowing only external European forms and implanting them artificially into Russian soil. It is possible to overcome such an approach through enlightenment and spirituality.

Dostoevsky tries to reveal the inner nature of Russian Europeanism in a polemic with Gradovsky, presented in the essay "Two Halves" (The Diary of a Writer, August, 1880).Dostoevsky insists on the indispensable combination of civic ideals with moral ideals, indicating that " In the origin of every people, of every nationality, the moral idea invariably preceded the origination of the nationality itself, since the former created the latter" [9]. The moral idea is embodied in religion. In modern Europe, this connection is broken. The moral idea is lost, so Europe cannot be a model for Russia, and Russian Europeanism comes down to "the mechanical transplantation to Russia of European forms." Russia has undoubted superiority over Europe, as its social and moral ideals come from Christianity. To illustrate this thesis Dostoevsky appeals to history, drawing a parallel with the Roman Empire, which for centuries was the "ideal of moral aspirations of the ancient world." But with the advent of Christianity "a collision of two diametrically opposed ideas occurred, the man-god encountered the God-man, Apollo of Belvedere encountered Christ. A compromise took place: the Empire embraced Christianity, while the Church accepted the Roman law and the Roman state." The subsequent split of the church (into the Western and Eastern ones) turned from being political into being ideological; in the Western (Catholic) church the state triumphed whereas in the Eastern (Orthodox) church it was Christ. "That state which embraced and again raised Christ has endured such dreadful secular sufferings from its enemies, the Tartars, want of order, serfdom, Europe and Europeanism - is still 
enduring so much suffering - that actually no real social formula in the spirit of love and Christian self-improvement has yet been elaborated in it."

Dostoevsky's understanding of the essence of the historical process was built in the coordinates of antiquity and Christianity. Let us refer to the opinion of Yu. Shichalin, who described this process as follows: "If the Greeks created the foundation of the European civilization, and the Romans showed the path to enter it, then Christians, as a new people, have demonstrated its supranational character for almost a millennium. Although the subsequent development of the European civilization was characterized by the development of national forms of Europeanism, individual countries and peoples who joined it reproduced its basic elements that appeared during the period under review, including the supranational significance of civilizational attitudes" [14].

\subsection{Myth about the Golden Age in the "The Adolescent" and "Demons" novels}

According to Dostoevsky, Christianity is definitely the spiritual nationwide principle. But the writer knows and remembers its historical predecessor - antiquity, which, having gone beyond the boundaries of a people and a separate ethnic group, gave rise to a culture of high thought and aesthetics of a national scale. This worldview also penetrates into Dostoevsky's literary texts. Thus the most europeanized of Dostoevsky's characters is Versilov in the novel "The Adolescent," who, by the writer's intentions, was to become the embodiment of a Russian European. According to V. Kantor, Dostoevsky's Russian European is convinced that he "caught the essence of the European culture, the European spirit in its integrity, in its nature, but not as a particular idea of countries belonging to Europe" [15]. The story Versilov told his adoptive son Arkady about a dream that he had had during his stay in Europe is essential for understanding his image in the novel, “ I don't know exactly what I did dream though: it was just as in the picture, a corner of the Grecian Archipelago, and time seemed to have gone back three thousand years; blue smiling waves, isles and rocks, a flowery shore, a view like fairyland in the distance, a setting sun that seemed calling to me - there's no putting it into words. It seemed a memory of the cradle of Europe, and that thought seemed to fill my soul, too, with a love as of kinship. Here was the earthly paradise of man: the gods came down from the skies, and were of one kin with men" [16]. Versilov awakens imbued with a sense of idyllic happiness. And this awakening becomes for him an awakening from illusions regarding modern Europe on the wanes. The character says of himself: "I, as a Russian, was the only European in Europe" [16].

The mythologem of the Golden Age is often exploited in Dostoevsky's works [17], and, as a rule, it refers to antiquity as a pan-European ancientry [18]. It is noteworthy that a similar dream, inspired by the same painting (Claude Lorren, "Asis and Galatea") is seen by Stavrogin in the novel "Demons": "A corner of the Greek archipelago; blue, caressing waves, islands and rocks, a luxuriant coastline, a magic panorama in the distance, an inviting sunset-words cannot express it. Here European mankind remembered its cradle, here were the first scenes from mythology, its earthly paradise... Here beautiful people lived!" [19]. As can be seen from the passages above, the texts combine many similar (often up to duplication) artistic details. We draw your attention to the fact that both Versilov and Stavrogin see their dreams when they are abroad, in Europe. Turning to Dostoevsky's working notes while writing the novel "Demons" shows that Stavrogin's future character is "without soil and cosmopolitan" [20]. The character's unrealized desire to self-actualize and become Russian leads him to suicide: "He was shot. The reason: I opened my eyes and saw too much and - could not stand that we are a demon of soil. He does not believe in God because he does not believe in his soil and nationality" [20]. O. Zolotko sees a definite connection here: for both Stavrogin and Versilov comprehension of the Golden Age theme with the images of ancient mythology and the painting by a European artist "organically appears from their foreign education, cosmopolitanism and common humanity" [21]. The characters' Europeanism turns into their disappointment in Europe.

\section{CONCLUSION}

In the works of Dostoevsky, who was brought up and nurtured by European and Russian culture, the question of Europeanism occupied an important place. The critical attitude of the writer and thinker towards Europeanism stems from his pochvennichestvo principles - he criticizes the blind imitation of Europe in Russia, because it is a rejection of the Russian pochva (soil). This imitation is all the more disastrous because Europe itself has lost its soil moving away from the spiritual values laid down by antiquity and Christianity. Dostoevsky sees the kinship between Russia and Europe based on precisely these values, which he called panhuman.

\section{ACKNOWLEDGMENT}

The reported study was funded by RFBR, project number 18-012-90037.

\section{REFERENCES}

[1] V. Uspensky, Asya Pekurovskaya, Dostoevsky's Passion: Writer's Desire Mechanisms, Znamya 3 (2005), Available at: https://magazines.gorky.media/znamia/2005/3/asyapekurovskaya-strasti-po-dostoevskomu-mehanizmyzhelanij-sochinitelya.html.

[2] N. Berdyaev, World outlook of Dostoevsky, Praha, 1923.

[3] F.M. Dostoevsky, Library: The Experiment of Reconstruction. Scientific Description, Nauka, 2005. 
[4] T.G. Malchukova, Antique and Christian traditions in the depiction of man and nature in the works of A.S. Pushkin, Petrozavodsk State Publ., 2007.

[5] A.A. Konovalov, A.R. Atabieva, Semantic concepts of Russia's orientation to Europe at the beginning of the XIX century, Kabardin-Balkar State University named after H.M. Berbekov 6-1(56) (2013) 151-156.

[6] V. Kantor, Russian European as a task for Russia, Herald of Europe 1 (2001) 78-81.

[7] V.N. Zakharov, Pochvennichestvo in Russian literature: the metaphor as ideologeme, Problems of historical poetics 10 (2012) 14-24.

[8] N.S. Dubovitskaya, The role of soil science in the formation of the worldview of F.M. Dostoevskyb Bulletin of GUU 21 (2013) 256-259.

[9] F.M. Dostoevsky, The Diary of a Writer, George Braziller, 1919.

[10] N.V. Devdariani, E.V. Rubtsova, To the question about the genre originality of "Diary of a Writer" by F.M. Dostoevsky, Baltic Humanitarian Journal 3(28) (2019) 271-273. DOI: 10.26140/bgz3-2019-0803-0067

[11]F.M. Dostoevsky, A number of articles on Russian literature, Available at:

https://rvb.ru/dostoevski/01 text/vol11/1861/75.htm.

[12] V.V. Borisova, "Diary of a writer" by F.M.

Dostoevsky in the focus of modern interpretations, Ideas and ideals 2(28) (2016) 128-137. DOI:

10.17212/2075-0862-2016-2.1-128-137

[13] B.N. Tikhomirov, Books that were with Dostoevsky during his stay in the Alekseevsky ravelin of the Peter and Paul Fortress (1849), Unknown Dostoevsky. Electronic scientific journa 3 (2015) 6883. DOI: $10.15393 / \mathrm{j} 10 . \operatorname{art} .2015 .2484$

[14] Yu.A. Shichalin, Error of Perspective, or Once Again on Russia and Europe, St. Tikhons Orthodox University for the Humanities 74 (2017) 93-112.

[15] V. Kantor, Op. cit., p. 80.

[16]F. Dostoevsky, A Raw Youth, The Macmillan Company, 1950.

[17] O.V. Zolotko, The Image of the "Golden Age" in the Works of F.M. Dostoevsky, dissertation for the degree of candidate of philological sciences, Moscow, 2017.

[18] T. Popovich, Europeism and antiquity in the narrative of Gogol, Starosvetsky pomeshchiki Srephanos 6(8) (2014) 61-68.

[19]F. Dostoevsky, Demons, Vintage Books, 1995.

[20]F. Dostoevsky, Full composition of writings: "Demons", vol.11, Nauka, 1974.

[21] O.V. Zolotko, Op. cit., p. 119. 